\title{
Apigenin inhibits glioma cell growth through promoting microRNA-16 and suppression of BCL-2 and nuclear factor- $\mathrm{KB} / \mathrm{MMP}-9$
}

\author{
XIN-JUN CHEN ${ }^{1}$, MIAN-YUN WU ${ }^{2}$, DENG-HUI LI ${ }^{1}$ and JIN YOU ${ }^{1}$ \\ ${ }^{1}$ Department of Neurosurgery, Zhongnan Hospital of Wuhan University, Wuhan, Hubei 430071; \\ ${ }^{2}$ Department of Biochemistry, School of Medicine, Wuhan University of Science and Technology, \\ Wuhan, Hubei 430065, P.R. China
}

Received June 12, 2015; Accepted June 6, 2016

DOI: $10.3892 / \mathrm{mmr} .2016 .5460$

\begin{abstract}
The present study aimed to investigate the effect of apigenin on glioma cells and to explore its potential mechanism. U87 human glioma cells treated with apigenin were used in the current study. Cell Counting Kit-8 solution and Annexin V-fluorescein isothiocyanate/propidium iodide Apoptosis Detection kit were used to analyze the effect of apigenin on U87 cell viability and apoptotic cell death. Reverse transcription-quantitative polymerase chain reaction analysis was also used to determine microRNA-16 (miR-16) and MMP-9 gene expression levels. Nuclear factor- $\mathrm{\kappa B}(\mathrm{NF}-\kappa \mathrm{B})$ and B-cell CLL/lymphoma 2 (BCL2) protein expression levels were determined using western blot analysis. An anti-miR-16 plasmid was constructed and transfected into U87 cells. The current study demonstrated that apigenin significantly decreased cell viability and induced apoptotic cell death of U87 cells in a dose-dependent manner. Additionally, it was demonstrated that apigenin significantly increased miR-16 levels, suppressed BCL2 protein expression and suppressed the NF-кB/MMP9 signaling pathway in U87 cells. Furthermore, downregulation of miR-16 using the anti-miR-16 plasmid reversed the effect of apigenin on cell viability, BCL2 protein expression and the NF- $\mathrm{\kappa B} / \mathrm{MMP}-9$ pathway in U87 cells. The results of the present study suggested that apigenin inhibits glioma cell growth through promoting miR-16 and suppression of BCL2 and NF-אB/MMP-9. In conclusion, the present study demonstrated the potential anticancer effects of apigenin on glioma cells.
\end{abstract}

Correspondence to: Mr. Xin-Jun Chen, Department of Neurosurgery, Zhongnan Hospital of Wuhan University, 169 Donghu Road, Wuchang, Wuhan, Hubei 430071, P.R. China

E-mail: xinjunchen@yeah.net

Key words: apigenin, glioma, microRNA-16, BCL-2, NF-kB, MMP-9

\section{Introduction}

Glioma is most commonly observed in adults, and has high severity and fatality rates. Due to the heterogeneity and abnormality of the tumor cells, glioma is rarely curable using current therapeutic methods, which include surgery and chemoradiotherapy (1). During the past decade, the median lifetime for patients with glioma is $\leq 12$ months. The majority of previous studies on glioma were conducted from the perspectives of histopathology and molecular biology (2). Recently, large amounts of evidence has demonstrated that in addition to glioma tumor cells that exhibit strong multiplication capacity and invasiveness, a set of cells, termed glioma stem cells, are also present in glioma tissue and exhibit similar characteristics to neural stem cells, such as infinite proliferation, self-renewing capacity and multi-lineage differentiation (3).

Studies on microRNAs (miRNAs) began early in 1993. The first miRNA was identified in Caenorhabditis elegans (4). miRNAs are a type of non-coding single stranded RNA with length of 19-25 nucleotides (5). With the progressing of molecular biology, studies demonstrated that miRNAs are involved in the occurrence and development of tumors (6). miRNAs may function as tumor suppressor genes to lower the activities of oncogenes, and also may oncogenes that lower the activities of tumor suppressors (6). miRNAs can regulate the relative expressions gene associated with tumor development (7). Mutations, deficiency, translocation and abnormality of mutual regulation of miRNAs may cause abnormal expression of miRNA target genes. miRNA-16 (miR-16) is located in chromosome 13ql4, which has been demonstrated to be associated with human tumors in a previous study (8). As a tumor suppressor gene, miR-16 expression is downregulated by regulating BMI1 proto-oncogene in mantle cell lymphoma side population cells, reducing tumor volume (9). miR-16 reduces the degree of malignancy of glioma by downregulating nuclear factor- $\kappa \mathrm{B}$ (NF- $\mathrm{KB}$ ) and matrix metalloproteinase (MMP-9), inhibiting invasiveness of glioma cell lines. Upregulation of miR-16 inhibits the expression of B-cell lymphoma 2 (BCL2), to promote tumor cell apoptosis (10).

Apigenin is a plant flavonoid compound present in numerous fruits, vegetables, beans and tea leaves (11). 
Previous studies demonstrated that it exerts various biological activities and pharmacological effects, including anticancer, anti-inflammation, antioxidant, anti-viral and immunoregulatory effects $(12,13)$. Previous studies of apigenin reported that it exerts cytotoxic effects on various cancer cells, including breast, lung, liver and prostate cancer (11,14-16). In the present study, the in vitro effects of apigenin on glioma were investigated and the results indicate that apigenin may provide a novel therapeutic approach for the treatment of glioma.

\section{Materials and methods}

Reagents. Dulbecco's modified Eagle's medium (DMEM) was purchased from Thermo Fisher Scientific, Inc. (Waltham, MA, USA). Fetal bovine serum (FBS) was purchased from Gibco (Thermo Fisher Scientific, Inc.). Cell Counting Kit-8 (CCK-8) solution was purchased from Wuhan Boster Biological Technology, Ltd. (Wuhan, China). Annexin V-fluorescein isothiocyanate (FITC)/propidium iodide Apoptosis Detection kit was purchased from BestBio Biotechnology Co., Ltd. (Shanghai, China). Protein lysis buffer and Bradford protein assay were purchased from Zhongshan Jinqiao Biotechnology Co., Ltd., (Beijing, China).

Cell culture. Human U87 glioma cells were obtained from the Cell Bank Type Culture Collection of the Chinese Academy of Sciences (Shanghai, China), and were cultured in DMEM supplemented with $10 \% \mathrm{FBS}$ and $100 \mathrm{U}$ penicillin/ml, $100 \mathrm{mg}$ streptomycin $/ \mathrm{ml}$ at $37^{\circ} \mathrm{C}$ in a humidified atmosphere of $5 \%$ $\mathrm{CO}_{2}$.

Cell viability. The effect of apigenin on U87 cell viability was determined using the CCK-8 kit. U87 cells were seeded onto 96-well plates $\left(1 \times 10^{3}\right.$ cells/well) and then incubated for $24 \mathrm{~h}$ following treatment with different concentrations $(0,1,5,10$, 20, 30 and $40 \mu \mathrm{g} / \mathrm{ml}$ ) of apigenin (Nanjing Pu Yi Biological Technology, Co., Ltd., Nanjing, China). Following treatment with apigenin, $10 \mu \mathrm{l}$ thawed CCK-8 solution was added to each well and incubated for $4 \mathrm{~h}$ at $37^{\circ} \mathrm{C}$. Subsequently, cell viability of was measured using the Varioskan Flash Multimode reader (Thermo Fisher Scientific, Inc.) at $450 \mathrm{~nm}$ with a reference wavelength of $600 \mathrm{~nm}$.

Cell apoptosis. The effect of apigenin $(0,10,20$ and $30 \mu \mathrm{g} / \mathrm{ml})$ on U87 apoptotic cell death was determined using the Annexin V-FITC/propidium iodide Apoptosis Detection kit according to the manufacturer's instructions and were analyzed by flow cytometry (Beckman Coulter, Inc., Brea, CA, USA).

Reverse transcription-quantitative polymerase chain reaction (RT-qPCR) analysis of $m i R-16$ and MMP-9 expression. Total RNA was isolated from U87 cells treated with apigenin using TRIzol reagent (Invitrogen; Thermo Fisher Scientific, Inc.) and cDNA was generated from $2 \mu \mathrm{g}$ RNA using RevertAid First Strand cDNA Synthesis kit (Thermo Fisher Scientific, Inc.) at $42^{\circ} \mathrm{C}$ for $1 \mathrm{~h}$ and $72^{\circ} \mathrm{C}$ for $5 \mathrm{~min}$. miR-16 and MMP-9 relative expression levels were examined using SYBR Green RT-qPCR (LightCycler 480 Roche, Switzerland). The primers used are presented in Table I. The thermocycling conditions were 30 cycles of denaturation at
Table I. Oligonucleotide of primers of target genes.

\begin{tabular}{lc}
\hline Gene & Primer (5'-3') \\
\hline miR-16 & \\
Sense & GCGGCA ACCCGTAGATCCGAA \\
Antisense & GTGCAGGGTCCGAGGT \\
U6 RNA & \\
Sense & CTCGCTTCGGCAGCACA \\
Antisense & AACGCT TCACGAATTTGCGT \\
MMP-9 & \\
Sense & CCCTGCGTATTTCCATTCAT \\
Antisense & ACCCCACTTCTTGTCAGCGTC \\
$\beta$-actin & \\
Sense & AAGCCTAAGGCCAACCGTGAAAAG \\
Antisense & TCAATGAGGTAGTCTGTCAGGT
\end{tabular}

miR-16, microRNA-16; MMP-9, matrix metalloproteinase-9.

$94^{\circ} \mathrm{C}$ for $15 \mathrm{sec}$, annealing at $57^{\circ} \mathrm{C}$ for $15 \mathrm{sec}$ and extension at $72^{\circ} \mathrm{C}$ for $30 \mathrm{sec}$. The expression of miR-16 was quantified using the $2^{-\Delta \Delta \mathrm{Cq}}$ method (17).

Western blot analysis of $N F-\kappa B$ and BCL-2 expression. U87 cells treated with apigenin were washed with ice-cold phosphate-buffered saline (PBS) and lysed in ice-cold lysis buffer (Zhongshan Jinqiao Biotechnology, Ltd.) for $30 \mathrm{~min}$. The samples were centrifuged at $23,000 \mathrm{x}$ g at $4^{\circ} \mathrm{C}$ for $10 \mathrm{~min}$. The supernatant was collected and the protein concentration was determined using the Bradford protein assay. Total protein $(50 \mu \mathrm{g})$ was separated with $12 \%$ SDS-PAGE and transferred onto a polyvinylidene difluoride membrane (EMD Millipore, Billerica, MA, USA). The membrane was blocked with 5\% non-fat milk then incubated with anti-NF- $\kappa \mathrm{B}$ (cat. no. sc-109) and BCL-2 (cat. no. sc-783) primary antibodies at a dilution of 1:1,000 (Santa Cruz Biotechnology, Inc., Dallas, TX, USA) at $4^{\circ} \mathrm{C}$ overnight. Subsequently, the membrane was washed with $0.1 \%$ Tween 20 in PBS and incubated with horseradish peroxidase-conjugated secondary antibody (1:5,000; Beyotime Institute of Biotechnology, Haimen, China; cat. no. A0208) for $2 \mathrm{~h}$ at room temperature. The protein bands were developed using horseradish peroxidase (Beyotime Institute of Biotechnology) and expression was determined using densitometry with Fujifilm Multi Gauge software, version 3.0 (Fujifilm, Tokyo, Japan).

Anti-miR-16 plasmid transfection. Anti-miR-16 plasmid (5'-CGCCAAUAUUUACGUGCUGCUA-3') and negative control plasmid (5'-CAGUACUUUUGUGUAGUACAA-3'). were synthesized by Sangon Biotech Co., Ltd. (Shanghai, China) and transfected into U87 cells using Lipofectamine 2000 (Invitrogen; Thermo Fisher Scientific, Inc.) according to the manufacturer's instructions.

Statistical analysis. Data are presented as the mean \pm standard error and statistical analysis was performed where appropriate with the two-tailed Student's t-test using SPSS software 
<smiles>O=c1cc(-c2ccc(O)cc2)oc2cc(O)cc(O)c12</smiles>

Figure 1. The chemical structure of apigenin

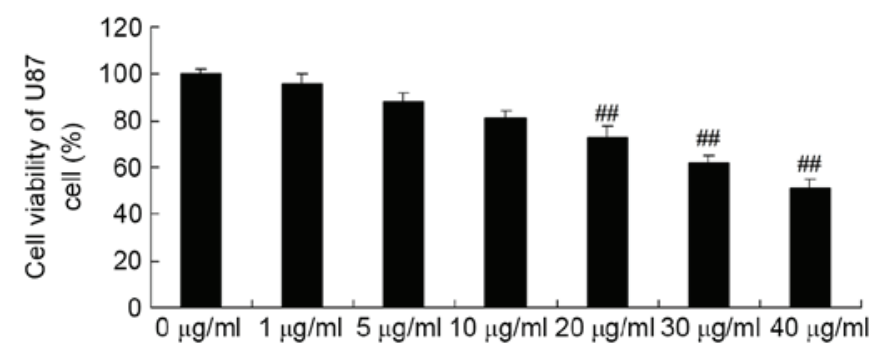

Figure 2. Apigenin inhibits the viability of U87 cells. ${ }^{\# \#} \mathrm{P}<0.01$ vs. $0 \mu \mathrm{g} / \mathrm{ml}$ apigenin group. Data are presented as the mean \pm standard error.

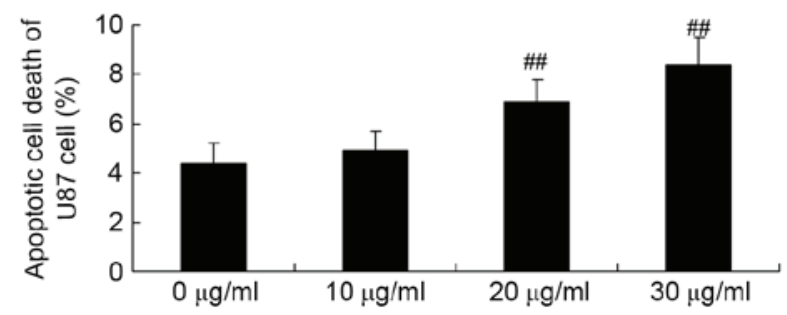

Figure 3. Apigenin induces apoptotic cell death of U87 cells. ${ }^{\# \#} \mathrm{P}<0.01 \mathrm{com}-$ pared with $0 \mu \mathrm{g} / \mathrm{ml}$ apigenin group. Data are presented as the mean \pm standard error.

(version 17.0; SPSS, Inc., Chicago, IL, USA). P<0.05 was considered to indicate a statistically significant difference.

\section{Results}

Apigenin inhibits U87 cell viability. The chemical structure of apigenin is presented in Fig. 1. The effects of apigenin on U87 cell viability were determined. As demonstrated in Fig. 2, apigenin $(20,30$, and $40 \mu \mathrm{g} / \mathrm{ml})$ significantly decreased cell viability in a dose-dependent manner compared with the control group $(\mathrm{P}=0.0081, \mathrm{P}=0.005$ and $\mathrm{P}=0.0004$, respectively).

Apigenin induces apoptotic cell death of U87 cell. Flow cytometry analysis was used to investigate the effect of apigenin on apoptotic cell death of U87 cells. The results demonstrated that 30 and $40 \mu \mathrm{g} / \mathrm{ml}$ apigenin significantly induced apoptotic cell death of U87 cells in a dose-dependent manner compared with the $0 \mu \mathrm{g} / \mathrm{ml}$ apigenin group $(\mathrm{P}=0.0032$ and $\mathrm{P}=0.0007$, respectively; Fig. 3).

Apigenin promotes miR-16 expression in U87 cells. To determine the underlying mechanism that mediates the effect of apigenin on U87 cells, the effect of apigenin on miR-16

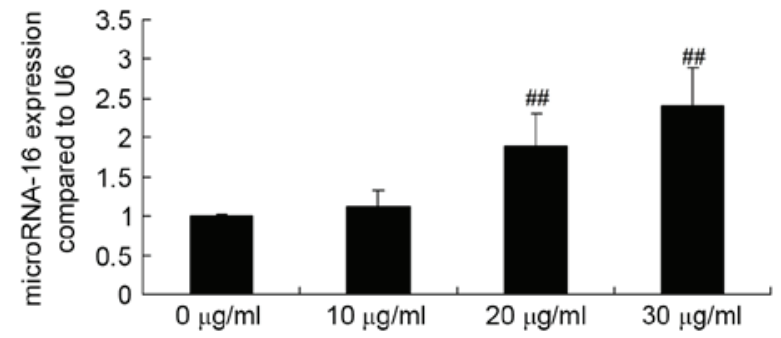

Figure 4. Apigenin promotes microRNA-16 expression in U87 cells. ${ }^{\#} \mathrm{P}<0.01$ vs. $0 \mu \mathrm{g} / \mathrm{ml}$ apigenin group. Data are presented as the mean \pm standard error.

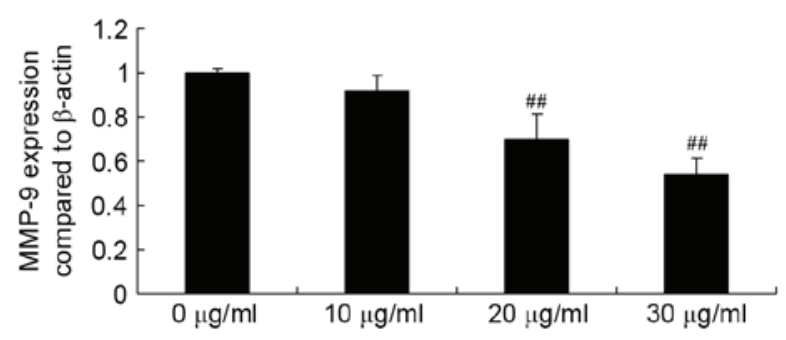

Figure 5. Apigenin inhibits MMP-9 expression of U87 cell. ${ }^{\# \#} \mathrm{P}<0.01$ vs. $0 \mu \mathrm{g} / \mathrm{ml}$ apigenin group. Data are presented as the mean \pm standard error. MMP-9, matrix metalloproteinase-9.

expression in U87 cells was examined. Briefly, U87 cells were treated with $0,10,20$ and $30 \mu \mathrm{g} / \mathrm{ml}$ apigenin for $24 \mathrm{~h}$, then subjected to RT-qPCR analysis. When U87 cells were treated with 20 or $30 \mu \mathrm{g} / \mathrm{ml}$ of apigenin, miR-16 expression was significantly increased compared with the control group $(\mathrm{P}=0.0005$ and $\mathrm{P}<0.0001$, respectively; Fig. 4).

Apigenin inhibits MMP-9 expression in U87 cells. Subsequently, the effect of apigenin on MMP-9 gene expression in U87 cells was determined by performing RT-qPCR analysis. The assay results demonstrated that exposure of U87 cells to 20 and $30 \mu \mathrm{g} / \mathrm{ml}$ apigenin for $24 \mathrm{~h}$ resulted in an significant decrease in MMP-9 gene expression levels compared with untreated control cells $(\mathrm{P}=0.0057$ and $\mathrm{P}=0.0022$, respectively; Fig. 5).

Apigenin inhibits $N F-\kappa B$ expression in U87 cells. To determine the effect of apigenin on NF-кB levels, western blotting was performed to detect NF- $\mathrm{KB}$ protein expression in $\mathrm{U} 87$ cells. The results of western blot analysis demonstrated that NF- $\mathrm{\kappa B}$ protein expression in U87 cells was significantly reduced by treatment with 20 and $30 \mu \mathrm{g} / \mathrm{ml}$ of apigenin for $24 \mathrm{~h}$ compared with the control group $(\mathrm{P}=0.0042$ and $\mathrm{P}=0.0013$, respectively; Fig. 6).

Apigenin inhibits BCL2 expression of U87 cell. The loss of BCL2 protein expression is an early event in apoptosis. Thus, the present study assessed the effect of apigenin on BCL2 protein expression using western blot analysis. As demonstrated in Fig. 7, when U87 cells were incubated with 20 and $30 \mu \mathrm{g} / \mathrm{ml}$ apigenin for $24 \mathrm{~h}, \mathrm{BCL} 2$ protein expression was significantly suppressed compared with the control group $(\mathrm{P}=0.0031$ and $\mathrm{P}=0.0009$, respectively).

Anti-miR-16 reverses the effect of apigenin on U87 cell viability. Whether anti-miR-16 reverses the effect of apigenin on U87 
A

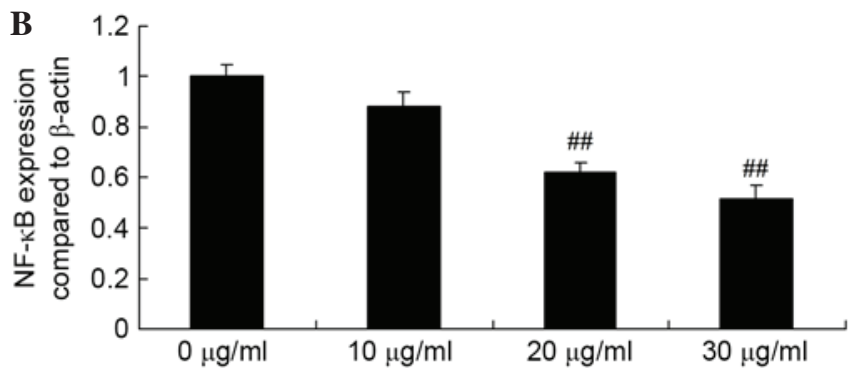

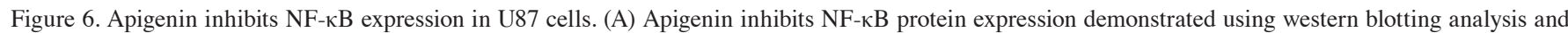
(B) statistical analysis of NF-kB protein expression in U87 cells. ${ }^{\# \#} \mathrm{P}<0.01$ vs. $0 \mu \mathrm{g} / \mathrm{ml}$ apigenin group. Data are presented as the mean \pm standard error. NF- $\mathrm{kB}$, nuclear factor- $\mathrm{kB}$.

A

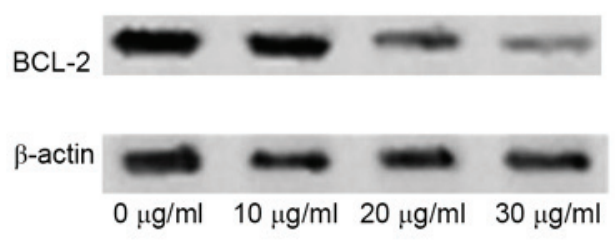

B

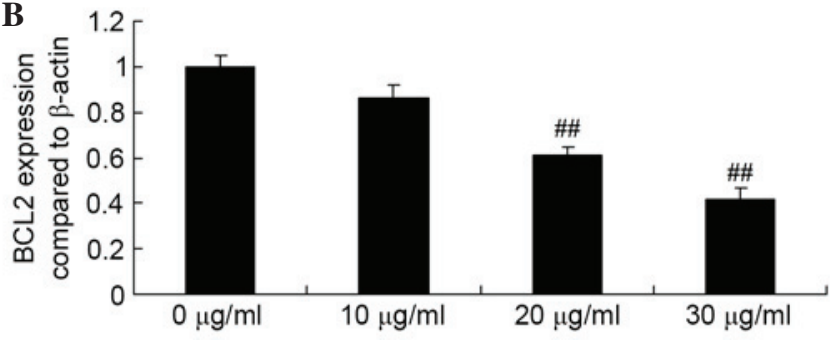

Figure 7. Apigenin inhibits BCL2 expression in U87 cells. (A) Apigenin inhibits BCL2 protein expression, demonstrated using western blotting analysis and (B) statistical analysis of BCL2 protein expression in U87 cell. ${ }^{\# \#} \mathrm{P}<0.01 \mathrm{vs} .0 \mu \mathrm{g} / \mathrm{ml}$ apigenin group. Data are presented as the mean \pm standard error. BCL2, B-cell CLL/lymphoma 2.

A

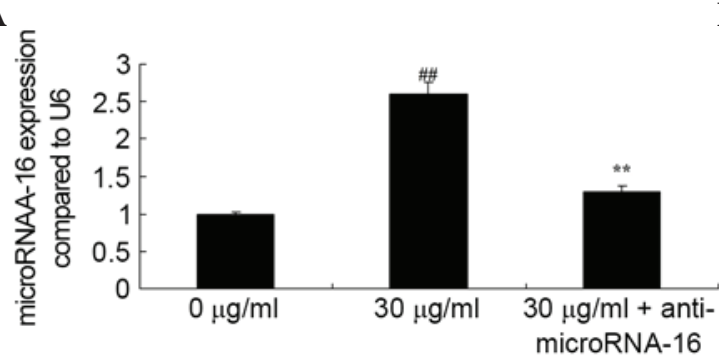

B

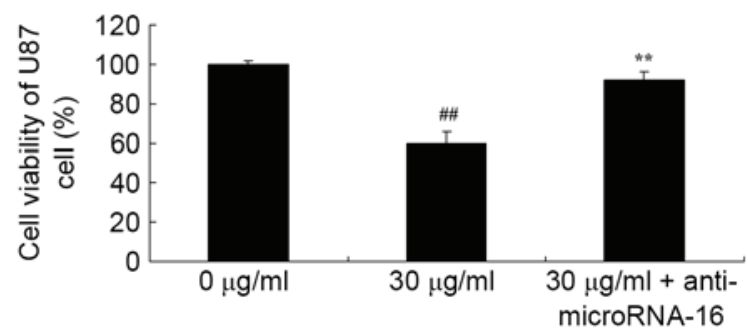

Figure 8. Anti-microRNA-16 reverses the effect of apigenin on U87 cell viability. (A) Anti-microRNA-16 effect on microRNA-16 gene expression and (B) can reverse the effect of apigenin on cell viability of $\mathrm{U} 87$ cell. ${ }^{\# \prime} \mathrm{P}<0.01 \mathrm{vs} .0 \mu \mathrm{g} / \mathrm{ml}$ apigenin group and ${ }^{* *} \mathrm{P}<0.01 \mathrm{vs}$. $30 \mu \mathrm{g} / \mathrm{ml}$ apigenin group. Data are presented as the mean \pm standard error.

cell viability was investigated. The results demonstrated that anti-miR-16 inhibited apigenin-induced miR-16 gene expression $(\mathrm{P}=0.0027$; Fig. $8 \mathrm{~A})$ and increased apigenin-suppressed viability of U87 cells compared with $30 \mu \mathrm{g} / \mathrm{ml}$ apigenin treatment ( $\mathrm{P}=0.0047$; Fig. 8B).

Anti-miR-16 reverses the effect of apigenin on BCL2 expression in U87 cells. To determine the molecular events involved in BCL2 expression in apigenin-induced apoptosis of U87 cells, the effect of anti-miR-16 on the level of BCL2 protein expression in U87 cells was analyzed. The results demonstrated that anti-miR-16 significantly increased BCL2 protein expression in U87 cell compared with $30 \mu \mathrm{g} / \mathrm{ml}$ apigenin treatment ( $\mathrm{P}=0.0022$; Fig. 9).

Anti-miR-16 reverses the effect of apigenin on $N F-\kappa B / M M P-9$ expression in U87 cells. To identify whether miR-16 is involved in the effect of apigenin on NF- $\mathrm{B} / \mathrm{MMP}-9$ expression in U87 cells, the effect of abti-miR-16 on the protein expression levels of NF- $\kappa \mathrm{B}$ and MMP-9 were determined. As demonstrated in Fig. 10, apigenin-inhibited NF- $\kappa$ B/MMP-9 levels were significantly increased by anti-miR-16 compared with $30 \mu \mathrm{g} / \mathrm{ml}$ apigenin $(\mathrm{P}=0.0072$ and $\mathrm{P}=0.0041$; Fig. 10).

\section{Discussion}

Glioma is a common tumor with high severity (18). Compared with malignant tumors in other locations, glioma is rarely transferred to sites out of the central nervous system (1). Additionally, glioma exhibits strong invasion capacity, and can infiltrate from primary lesions to other cerebral tissue or metastasize to distant sites far from the primary lesions (19). As a result, the edges of the primary tumor are unclear. Combined with its strong invasive capacities, mortality rates of patients with glioma are high (20). Consequently, even following treatment, including surgery and chemoradiotherapy, survival periods 
A

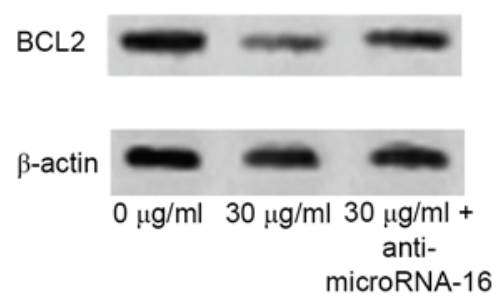

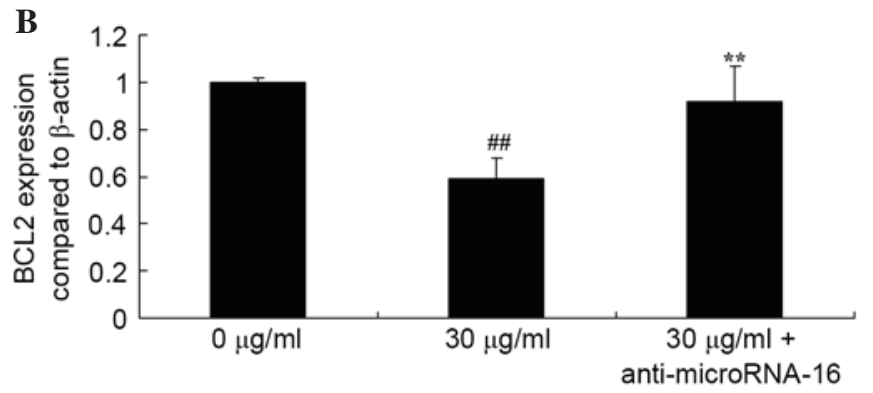

Figure 9. Anti-microRNA-16 can reverse the effect of apigenin on BCL2 expression in U87 cells. (A) Anti-microRNA-16 can reverse BCL2 expression as demonstrated using western blotting analysis and (B) statistical analysis of BCL2 protein expression in U87 cells. ${ }^{\# \#} \mathrm{P}<0.01 \mathrm{vs} .0 \mu \mathrm{g} / \mathrm{ml}$ apigenin group, ${ }^{* *} \mathrm{P}<0.01$ vs. $30 \mu \mathrm{g} / \mathrm{ml}$ apigenin group. Data are presented as the mean \pm standard error. BCL2, B-cell CLL/lymphoma 2 .
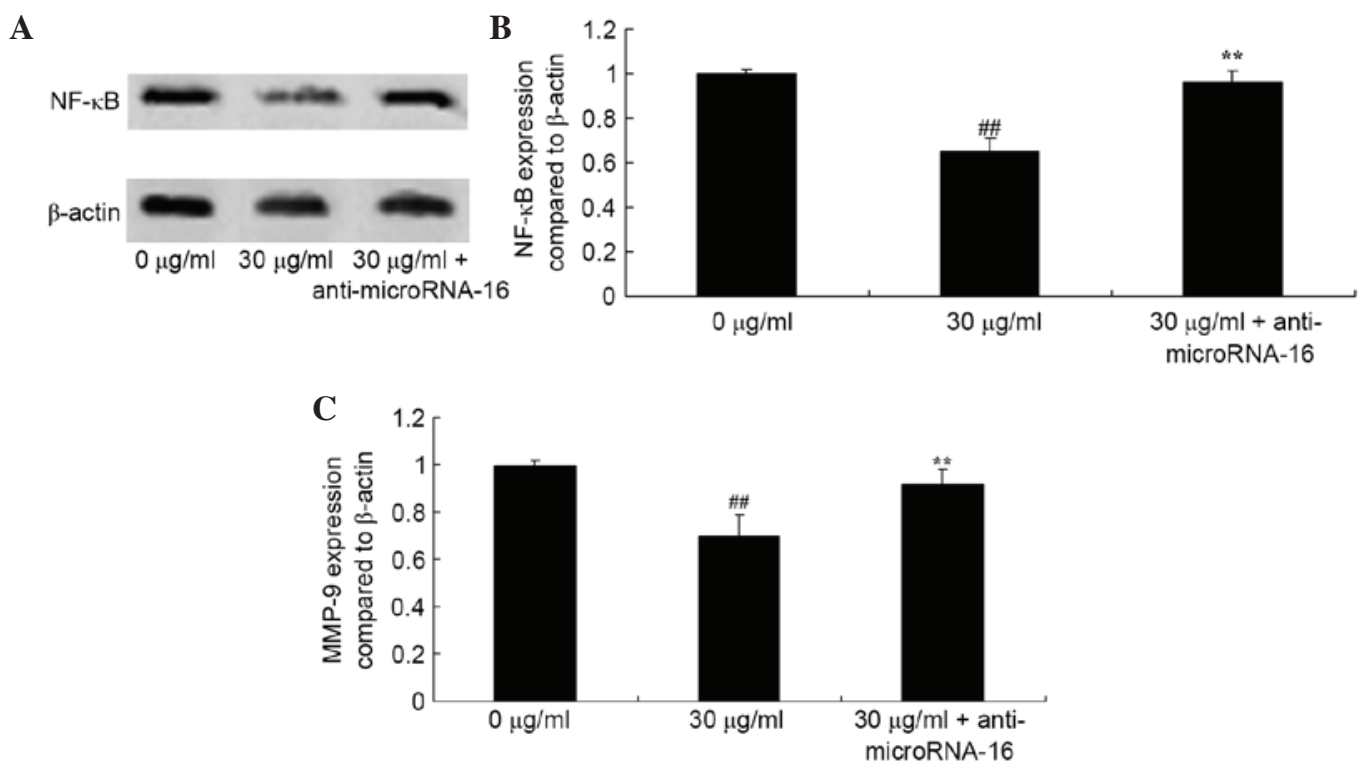

Figure 10. Anti-microRNA-16 can reverse the effect of apigenin on NF-кB/MMP-9 of U87 cells. (A) Anti-microRNA-16 can reverse NF-кB expression demonstrated using western blotting analysis and (B) statistical analysis of NF- $\mathrm{\kappa B}$ protein expression and (C) MMP-9 expression. ${ }^{\# \#} \mathrm{P}<0.01 \mathrm{vs} .0 \mu \mathrm{g} / \mathrm{ml}$ apigenin group

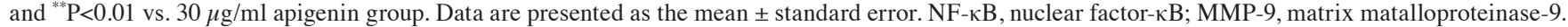

of patients with glioma $\leq 15$ months (21). It is particularly important to identify novel molecules that participate in the metastasis and invasion of glioma. The present study demonstrated that apigenin significantly decreased cell viability and induced apoptotic cell death of U87 cells in a dose-dependent manner. Previous studies demonstrated that apigenin inhibits the proliferation of human bladder cancer (11), ovarian cancer cells (14) and lung cancer (15).

Additionally, multiple studies have demonstrated that miRNAs are important in tumor physiological and pathological processes, including growth, proliferation, apoptosis, lipid metabolism, hormone secretion and tumorigenesis (4). miRNAs can be regarded as oncogenes or tumor suppressor genes (7). Particularly, studies have reported that miRNAs are involved in cell differentiation, proliferation and invasion (5). A previous study reported that miR-16 reduced the metastasis and invasion of glioma cells by inhibiting MMP-9 (22). Additionally, another previous report demonstrated that increased miR-16 inhibited the proliferation of glioma and accelerated its apoptosis (23). To the best of our knowledge, the current study demonstrated for the first time that apigenin significantly increased miR-16 levels in U87 cells. Yang et al (22) previously reported that miR-16 reduced glioma cell growth via suppression of BCL2 and the NF- $\mathrm{B} / \mathrm{MMP} 9$ signaling pathway.

The BCL 2 genes are localized at chromosome 18q21 and the encoded protein products can reverse the apoptosis-promoting effects of c-myc proteins, stabilize mitochondrial function and structures, and disrupt the activity of caspase enzymes via antagonism of p53 proteins (24). Thus, BCL2 inhibits cell apoptosis induced by various factors and participates in the dynamic equilibrium that regulates proliferation and apoptosis (25). Abnormal increases in BCL2 expression causes cells with abnormal changes to avoid apoptosis (25). Increased accumulation of genetic abnormal events is a prerequisite of cell transformation and tumorigenesis (26). Infiltrative growth is a distinctive feature of glioma and the invasive capability is proportional to its severity. Studies using glioma cell lines in vitro demonstrated that BCL2 promoted the synthesis, secretion and activity of MMPs to increase the infiltrative capacities of glioma cells $(27,28)$. The present study demonstrated that treatment with apigenin significantly suppressed BCL2 protein 
expression in U87 cells. Additionally, Shukla and Gupta (16) concluded that apigenin induced apoptosis of DU145 human prostate carcinoma cells by altering the BCL2 associated X protein/BCL2 ratio (16).

Previous findings have demonstrated that $\mathrm{NF}-\kappa \mathrm{B}$ is a important factor during inflammation (29). As one of most important transcription factors discovered in recent years, $\mathrm{NF}-\kappa \mathrm{B}$ was named as it sequence-specifically binds with enhancer $\kappa \mathrm{B}$ of $\kappa$ light chain of B cell immunoglobulins (30). $\mathrm{NF}-\kappa \mathrm{B}$ is involved in vascularization and tumor spread through regulation of vascular endothelial growth factor and interleukin-8; it promotes the transcription of MMPs to degrade extracellular matrix (31). Thus, $\mathrm{NF}-\kappa \mathrm{B}$ may promote tumor infiltration to surrounding tissues and the metastasis of breast cancer cells (31). The current study identified that apigenin significantly reduced $\mathrm{NF}-\kappa \mathrm{B}$ protein expression in U87 cells. Chang et al (32) demonstrated that apigenin protects against adjuvant-induced arthritis via inhibiting the purinergic receptor $\mathrm{P} 2 \mathrm{X} 7 / \mathrm{NF}-\kappa \mathrm{B}$ pathway.

A study investigating chronic myeloid leukemia by Li et al (23) demonstrated that miR-15a and miR-16-1 expression was increased and BCL2 was decreased in glioma cells. miR-15a and miR-16-1 negatively regulate BCL2 expression at the post-transcriptional level. BCL2 was demonstrated to be a target gene of miR-16, which significantly inhibited the 3'UTR region of BCL2 transcripts (22). A previous in vivo experiment demonstrated that miR-16 directly inhibited protein expressions of BCL2 to induce early apoptosis of glioma cells in human brain (22). The altered activity of NF- $\mathrm{B} / \mathrm{MMP}-9$ signaling pathways in brain glioma promoted invasion (33). In vitro experiments demonstrated that, as a cancer suppressor gene, miR-16 reduced the proliferation and invasion of brain glioma via inhibiting the gene expressions NF- $\kappa \mathrm{B}$ and MMP-9 (22). In the present study, apigenin suppressed the NF- $\kappa \mathrm{B} / \mathrm{MMP} 9$ signaling pathway in U87 cells. Palmieri et al (12) reported that apigenin inhibits the TNF $\alpha$-induced expression of MMP-9. Additionally, the current study demonstrated that anti-miR-16 reversed the effect of apigenin on cell viability, BCL2 protein expression and the NF- $\kappa \mathrm{B} / \mathrm{MMP}-9$ pathway in U87 cells. Yang et al (22) reported that miR-16 reduced the proliferation of glioma cells via suppression of BCL2 expression and NF- $\mathrm{B} / \mathrm{MMP} 9$ signaling.

In conclusion, the present study demonstrated that apigenin reduced glioma viability through increased expression of miR-16, and suppression of BCL-2 and NF-кB/MMP-9. These results suggested that apigenin may represent a valuable cancer therapeutic option for the treatment of glioma.

\section{References}

1. Okada H, Kalinski P, Ueda R, Hoji A, Kohanbash G, Donegan TE, Mintz AH, Engh JA, Bartlett DL, Brown CK, et al: Induction of CD8+ T-cell responses against novel glioma-associated antigen peptides and clinical activity by vaccinations with (alpha)-type 1 polarized dendritic cells and polyinosinic-polycytidylic acid stabilized by lysine and carboxymethylcellulose in patients with recurrent malignant glioma. J Clin Oncol 29: 330-336, 2011.

2. Diez Valle R, Slof J, Galvan J, Arza C, Romariz C and Vidal C; VISIONA study researchers: Observational, retrospective study of the effectiveness of 5-aminolevulinic acid in malignant glioma surgery in Spain (The VISIONA study). Neurologia 29: 131-138, 2014.
3. Morrison LC, McClelland R, Aiken C, Bridges M, Liang L, Wang X, Di Curzio D, Del Bigio MR, Taylor MD and Werbowetski-Ogilvie TE: Deconstruction of medulloblastoma cellular heterogeneity reveals differences between the most highly invasive and self-renewing phenotypes. Neoplasia 15: 384-398, 2013

4. Ouyang Q, Xu L, Cui H, Xu M and Yi L: MicroRNAs and cell cycle of malignant glioma. Int J Neurosci 126: 1-9, 2016.

5. Wang BC and Ma J: Role of MicroRNAs in Malignant Glioma. Chin Med J (Engl) 128: 1238-1244, 2015.

6. Hu E, Wang D, Zhang X, Li J, Hu Y, Gong H and Liu E: Four common polymorphisms in microRNAs and the risk of adult glioma in a chinese case-control study. J Mol Neurosci 51: 933-940, 2013.

7. Feng SY, Dong CG, Wu WK, Wang XJ, Qiao J and Shao JF: Lentiviral expression of anti-microRNAs targeting miR-27a inhibits proliferation and invasiveness of U87 glioma cells. Mol Med Rep 6: 275-281, 2012.

8. Venturutti L, Cordo Russo RI, Rivas MA, Mercogliano MF, Izzo F, Oakley RH, Pereyra MG, De Martino M, Proietti CJ, Yankilevich P, et al: MiR-16 mediates trastuzumab and lapatinib response in ErbB-2-positive breast and gastric cancer via its novel targets CCNJ and FUBP1. Oncogene: May 9, 2016 (Epub ahead of print)

9. Chen RW, Bemis LT, Amato CM, Myint H, Tran H, Birks DK, Eckhardt SG and Robinson WA: Truncation in CCND1 mRNA alters miR-16-1 regulation in mantle cell lymphoma. Blood 112: 822-829, 2008

10. Han J and Chen Q: MiR-16 modulates temozolomide resistance by regulating BCL-2 in human glioma cells. Int J Clin Exp Pathol 8: 12698-12707, 2015.

11. Shi MD, Shiao CK, Lee YC and Shih YW: Apigenin, a dietary flavonoid, inhibits proliferation of human bladder cancer T-24 cells via blocking cell cycle progression and inducing apoptosis. Cancer Cell Int 15: 33, 2015.

12. Palmieri D, Perego P and Palombo D: Apigenin inhibits the TNFalpha-induced expression of eNOS and MMP-9 via modulating Akt signalling through oestrogen receptor engagement. Mol Cell Biochem 371: 129-136, 2012.

13. Zhang S, Liu X, Sun C, Yang J, Wang L, Gong L and Jing Y: Apigenin attenuates experimental autoimmune myocarditis by modulating Th1/Th 2 cytokine balance in mice. Inflammation 39: 678-686, 2016.

14. Suh YA, Jo SY, Lee HY and Lee C: Inhibition of IL-6/STAT3 axis and targeting Axl and Tyro3 receptor tyrosine kinases by apigenin circumvent taxol resistance in ovarian cancer cells. Int J Oncol 46: 1405-1411, 2015.

15. Bruno A, Siena L, Gerbino S, Ferraro M, Chanez P, Giammanco M, Gjomarkaj M and Pace E: Apigenin affects leptin/leptin receptor pathway and induces cell apoptosis in lung adenocarcinoma cell line. Eur J Cancer 47: 2042-2051, 2011.

16. Shukla S and Gupta S: Molecular mechanisms for apigenin-induced cell-cycle arrest and apoptosis of hormone refractory human prostate carcinoma DU145 cells. Mol Carcinog 39: 114-126, 2004.

17. Leylabadlo HE, Yekani M and Ghotaslou R: Helicobacter pylori hopQ alleles (type I and II) in gastric cancer. Biomed Rep 4: 601-604, 2016.

18. Solomon MT, Selva JC, Figueredo J, Vaquer J, Toledo C, Quintanal N, Salva S, Domíngez R, Alert J, Marinello JJ, et al: Radiotherapy plus nimotuzumab or placebo in the treatment of high grade glioma patients: Results from a randomized, double blind trial. BMC Cancer 13: 299, 2013.

19. Morokoff A, Ng W, Gogos A and Kaye A: Molecular subtypes, stem cells and heterogeneity: Implications for personalised therapy in glioma. J Clin Neurosci 22: 1219-1226, 2015.

20. Sizoo EM, Pasman HR, Dirven L, Marosi C, Grisold W, Stockhammer G, Egeter J, Grant R, Chang S, Heimans JJ, et al: The end-of-life phase of high-grade glioma patients: A systematic review. Support Care Cancer 22: 847-857, 2014.

21. Siu A, Wind JJ, Iorgulescu JB, Chan TA, Yamada Y and Sherman JH: Radiation necrosis following treatment of high grade glioma-a review of the literature and current understanding. Acta Neurochir (Wien) 154: 191-201, 2012.

22. Yang TQ, Lu XJ, Wu TF, Ding DD, Zhao ZH, Chen GL, Xie XS, Li B, Wei YX, Guo LC, et al: MicroRNA-16 inhibits glioma cell growth and invasion through suppression of BCL2 and the nuclear factor-kappaB1/MMP9 signaling pathway. Cancer Sci 105: 265-271, 2014. 
23. Li X, Ling N, Bai Y, Dong W, Hui GZ, Liu D, Zhao J and Hu J: MiR-16-1 plays a role in reducing migration and invasion of glioma cells. Anat Rec (Hoboken) 296: 427-432, 2013.

24. Wang Q, Li A, Wang H and Wang J: Knockdown of apoptosis repressor with caspase recruitment domain (ARC) increases the sensitivity of human glioma cell line U251MG to VM-26. Int J Clin Exp Pathol 5: 555-561, 2012.

25. Jia G, Wang Q, Wang R, Deng D, Xue L, Shao N, Zhang Y, Xia X, Zhi F and Yang Y: Tubeimoside-1 induces glioma apoptosis through regulation of $\mathrm{Bax} / \mathrm{Bcl}-2$ and the $\mathrm{ROS} / \mathrm{Cytochrome}$ C/Caspase-3 pathway. Onco Targets Ther 8: 303-311, 2015.

26. Li CL, Chang L, Guo L, Zhao D, Liu HB, Wang QS, Zhang P, Du WZ, Liu X, Zhang HT, et al: beta-elemene induces caspase-dependent apoptosis in human glioma cells in vitro through the upregulation of Bax and Fas/ FasL and downregulation of Bcl-2. Asian Pac J Cancer Prev 15: 10407-10412, 2014.

27. Wick W, Wild-Bode C, Frank B and Weller M: BCL-2-induced glioma cell invasiveness depends on furin-like proteases. J Neurochem 91: 1275-1283, 2004.

28. Yang TQ, Lu XJ, Wu TF, Ding DD, Zhao ZH, Chen GL, Xie XS Li B, Wei YX, Guo LC, et al: MicroRNA-16 inhibits glioma cell growth and invasion through suppression of BCL2 and the nuclear factor-kappaB1/MMP9 signaling pathway. Cancer Sci 105: 265-271, 2014.
29. Zhu LB, Jiang J, Zhu XP, Wang TF, Chen XY, Luo QF, Shu Y, Liu ZL and Huang SH: Knockdown of Aurora-B inhibits osteosarcoma cell invasion and migration via modulating PI3K/Akt/NF-kappaB signaling pathway. Int J Clin Exp Pathol 7: 3984-3991, 2014

30. Du Z, Whitt MA, Baumann J, Garner JM, Morton CL, Davidoff $A M$ and Pfeffer LM: Inhibition of type I interferon-mediated antiviral action in human glioma cells by the IKK inhibitors BMS-345541 and TPCA-1. J Interferon Cytokine Res 32: 368-377, 2012.

31. Kesanakurti D, Chetty C, Bhoopathi P, Lakka SS, Gorantla B, Tsung AJ and Rao JS: Suppression of MMP-2 attenuates TNF-alpha induced NF-kappaB activation and leads to JNK mediated cell death in glioma. PLoS One 6: e19341, 2011.

32. Chang X, He H, Zhu L, Gao J, Wei T, Ma Z and Yan T: Protective effect of apigenin on Freund's complete adjuvant-induced arthritis in rats via inhibiting $\mathrm{P} 2 \mathrm{X} 7 / \mathrm{NF}-\kappa \mathrm{B}$ pathway. Chem Biol Interact 236: 41-46, 2015.

33. Jiang L, Wu J, Yang Y, Liu L, Song L, Li J and Li M: Bmi-1 promotes the aggressiveness of glioma via activating the NF-kappaB/MMP-9 signaling pathway. BMC Cancer 12: 406 , 2012. 